\title{
Effect of some environmental factors on seed germination of Eryngium caeruleum M. Bieb. populations
}

\author{
Mohammad Rezvani ${ }^{\star *}$ and Faezeh Zaefarian ${ }^{2}$
}

Received: January 1, 2017

Accepted: March 8, 2017

\begin{abstract}
The effects of alternating and constant temperatures and light regimes, osmotic and salt stress and $\mathrm{pH}$ were tested on seed germination in four populations of Eryngium caeruleum. Laboratory experiments revealed that the four populations exhibited different responses to alternating temperature and light conditions. Alternating temperature and photoperiod had a greater positive effect on seed germination compared to complete darkness. The optimal constant temperature within $10^{\circ} \mathrm{C}$ to $15^{\circ} \mathrm{C}$ for seed germination of each population was determined in a light/ dark photoperiod. Seed germination severely decreased under water stress and was completely inhibited at -0.8 MPa osmotic potential. Saline stress sharply decreased germination percentage. Germination was restricted by $\mathrm{pH}$ lower and higher than 5 and 8, respectively. The information obtained from this study helps to fill the gap of knowledge about seed germination requirements of E. caeruleum and enhance our understanding of this species distribution and its potential to develop in stressful and/or new habitats.
\end{abstract}

Keywords: alternating and constant temperatures, germination, light, $\mathrm{pH}$, salt and osmotic stress

\section{Introduction}

The distribution of plant species among habitats is determined by a wide range of climatic and edaphic factors. Habitat heterogeneity combined with natural selection often lead to multiple, genetically distinct ecotypes within a single species (Linhart \& Grant 1996). Thus, ecotypes are populations of a particular species that are evolutionally adapted to specific environmental conditions. These ecotypes, or populations that occurring in distinct habitats, vary from one another in morphological traits such as shape, size, or leaf color (Krawczyk \& Krawczyk 2000), as well as traits related to seed germination.

Seed germination is considered to be the most vulnerable and crucial phase in a plants life cycle (Finch-
Savage \& Leubner-Metzger 2006). Temperature is known to be one of the most influential environmental factors for seed germination (Finch-Savage \& Leubner-Metzger 2006). Some plant seeds germinate at temperatures above a certain minimum threshold, whereas others need daily fluctuations in temperature above and below a specific temperature. The germination of many annuals plants increases with alternating temperatures (Bazzaz 1979). Temperature is also related to germination through altering levels of gibberellins and abscisic acid in the seed (FinchSavage \& Leubner-Metzger 2006). Salt stress and water deficit are key environmental factors that can hinder or halt seed germination. Soil $\mathrm{pH}$ is an edaphic factor that can influence the distribution of plants, and some plant species germinate in a wide $\mathrm{pH}$ range (Yazdi et al. 2013;

\footnotetext{
${ }^{1}$ Department of Agronomy and Plant Breeding, Qaemshahr Branch, Islamic Azad University, 4765161964, Qaemshahr, Iran

${ }^{2}$ Department of Agronomy, Sari Agricultural Sciences and Natural Resources University, Sari, 4818168984, Mazandaran, Iran

*Corresponding author: m_rezvani52@yahoo.com
} 
Rezvani \& Yazdi 2013), while for others it can be a limiting factor (Amini et al. 2015).

The genus Eryngium of the family Apiaceae includes about 250 species distributed throughout Eurasia, North Africa, North and South America and Australia. The genus Eryngium is considered to be the most species-rich genus of Apiaceae (Pimenov \& Leonov 1993). Species of Eryngium are distributed among a wide range of environmental conditions in Iran, from semi-arid to temperate regions (Karimi 2001). Eryngium caeruleum is a perennial herbaceous plant that is native to northern Iran (Ghahreman 1997). This plants life cycle begins in mid October from permanent roots in the soil and/or seed, and reaches maturity late in July (Karimi 2001). Eryngium caeruleum is used in folk medicinal and as a spice plant in different regions of Iran. Root, leaf, stem and inflorescence of the plant have medicinal properties. The fresh leaves of the plant have a good taste and are aromatic, and so it is used in traditional cooking (Khoshbakht et al. 2006; Daneshfar et al. 2014). Species of Eryngium are propagated by seed production, transplanted plantlets or by cuttings (Armitage 1993). The growth rate of Eryngium is very slow, so their ability to respond to habitat disruption is weak (Everett 1960). Seeds of species of Apiaceae are often morphologically or morphophysiologically dormant (Finch-Savage \& Leubner-Metzger 2006).

Nothing has been published on the factors that affect seed germination of E. caeruleum and its ability to tolerate conditions of saline and drought. The aims of the present study were to: (1) determine the effects of alternating and constant temperature and light regimes, and osmotic and salt stress in different temperature regimes and $\mathrm{pH}$, on seed germination of four populations of E. caeruleum; and (2) document how the growth conditions of the mother plant affect traits of seed germination.

\section{Materials and methods}

\section{Seed source}

Seeds of four populations of Eryngium caeruleum M. Bieb. were collected in late July 2014, from 300 naturally matured and completely senesced plants. The climatic and geographical characteristics of the region of where the populations are growing are shown (Tab. 1). Seeds were separated from chaff and stored in paper bags at $20 \pm 5{ }^{\circ} \mathrm{C}$ before starting the experiments.

\section{Seed germination test}

Prior to the experiments, thirty seeds of Eryngium caeruleum were evaluated for viability by $1 \%$ tetrazolium chloride solution (Peters 2000).

Seeds were sterilized with $1 \%$ sodium hypochloride for 2 minutes and then washed with distilled water five times. For each experiment 30 disinfected seeds were placed on two layers of Whatman No. 1 filter paper and moistened with 6 $\mathrm{ml}$ distilled water or test solutions. Petri dishes were sealed with Parafilm, to inhibit water reduction, and incubated. Fluorescent lamps were used to produce a photosynthetic photon flux intensity of $150-\mu \mathrm{mol} \mathrm{m}^{-2} \mathrm{~s}^{-1}$. Germinated seeds, as indicated by the visible protrusion of about $1 \mathrm{~mm}$ of the radicle, were counted after 15 days.

\section{Effects of alternating temperature and light regimes on seed germination}

Initial seed germination of seeds of E. caeruleum from the study populations was evaluated in different alternating temperatures, including 20/10, 25/15, 30/10 and $35 / 15^{\circ} \mathrm{C}$ (day/night), in a 12/12-hour light/dark (day/night) photoperiod and complete darkness. For complete darkness, Petri dishes were wrapped in two layers of aluminum foil.

\section{Constant temperature and light regime}

Germination of seeds from the study populations was evaluated in constant temperatures, including $10,15,20$, $25,30,35,40,45$ and $50^{\circ} \mathrm{C}$, both in a 12/12-hour light/ dark (day/night) photoperiod and complete darkness. For complete darkness regime Petri dishes were covered in two layers of aluminum foil.

\section{Effect of osmotic potential on seed germination in different temperature regimes}

The effect of osmotic stress on the germination of seeds from the study populations was evaluated in solutions of $0,-0.1,-0.2,-0.4,-0.6,-0.8$ and $-1 \mathrm{MPa}$, prepared by dissolving 0, 91.6, 129.5, 183.1, 224.2, 258.9 and 289.8 polyethylene glycol 6000 (Merck, Darmstadt, Germany) in $1 \mathrm{~L}$ of distilled water (Michel \& Kaufaman 1973). Seeds

Table 1. Geographical and weather parameters of populations growing locations.

\begin{tabular}{|c|c|c|c|c|c|c|}
\hline Populations & Coordinates & Height [m] & Rainfall (mm] & $\begin{array}{c}\text { Average } \\
\text { temperature }\left({ }^{\circ} \mathrm{C}\right]\end{array}$ & $\begin{array}{c}\text { Minimum } \\
\text { temperature }\left[^{\circ} \mathrm{C}\right]\end{array}$ & $\begin{array}{c}\text { Maximum } \\
\text { temperature }\left({ }^{\circ} \mathrm{C}\right]\end{array}$ \\
\hline P1 & $36^{\circ} 49^{\prime} \mathrm{N} ; 53^{\circ} 26^{\prime} \mathrm{E}$ & 50.02 & 665 & 16.01 & -5.40 & 38.20 \\
\hline P2 & $36^{\circ} 66^{\prime} \mathrm{N} ; 53^{\circ} 66^{\prime} \mathrm{E}$ & -17.2 & 665 & 16.01 & -5.20 & 38.60 \\
\hline P3 & $36^{\circ} 48^{\prime} \mathrm{N} ; 53^{\circ} 28^{\prime} \mathrm{E}$ & 147 & 539.80 & 12.88 & -5.20 & 38.60 \\
\hline P4 & $36^{\circ} 42^{\prime} \mathrm{N} ; 53^{\circ} 36^{\prime} \mathrm{E}$ & 1875 & 306.10 & 10.08 & -15.40 & 35.80 \\
\hline
\end{tabular}


were incubated in different alternating temperatures 20/10, $25 / 15$ and $35 / 15^{\circ} \mathrm{C}$ day/night in a $12 / 12$-hour light/dark (day/night) photoperiod.

\section{Effect of $\mathrm{NaCl}$ concentration on seed germination in different temperature regimes}

Solutions of different concentrations of $\mathrm{NaCl}$ (Merck, Darmstadt, Germany), including 0 (distilled water), 20, 40, 80 and $160 \mathrm{mM}$, were prepared (Rao et al. 2008). Germination of seeds of the study populations was evaluated in different alternating temperatures including $20 / 10,25 / 15$ and $35 / 15^{\circ} \mathrm{C}$ (day/night) in a 12/12-hour light/dark (day/night) photoperiod.

\section{Effect of pH on seed germination}

The impact of $\mathrm{pH}$, from 3 up to 11, on germination of seeds of the study populations was evaluated by using the buffer solutions described by Chachalis \& Reddy (2000). A 2-mM potassium hydrogen phthalate buffer solution was adjusted to $\mathrm{pH} 3$ or 4 with $1 \mathrm{~N} \mathrm{HCl}$. A 2-mM solution of 2-(N-morpholino) ethanesulfonic acid was adjusted to $\mathrm{pH} 5$ or 6 with $1 \mathrm{~N} \mathrm{NaOH}$. A 2-mM solution of $\mathrm{N}-(2-$ hydroxymethyl) piperazine-N9-(2-ethanesulfonic acid) was adjusted to $\mathrm{pH} 7$ or 8 with $1 \mathrm{~N} \mathrm{NaOH}$, and a buffer with a pH of 9 or 10 was prepared with 2-mM N-tris(hydroxymethyl)methylglycine and adjusted with $1 \mathrm{~N} \mathrm{NaOH}$. Seeds were incubated at $25 / 15{ }^{\circ} \mathrm{C}$ (day/night) temperature and a 12/12-hours light/dark (day/night) photoperiod.

\section{Statistical analyses}

Experiments were conducted in a complete randomized design with three replicates, with each experiment being performed twice. All data were subjected to arcsin transformation to improve homogeneity. According to Bartlett's test, the transformation of the data of the constant and alternating temperatures, and salt and osmotic stress experiments did not improve homogeneity, and so the analysis was conducted on non-transformed data as percentages. Arcsin transformation improved the $\mathrm{pH}$ data and so transformed data were used for analysis.

The data from the alternating and constant temperatures and $\mathrm{pH}$ experiments were subjected to analysis of variance (ANOVA) and means were separated by using of Fisher's protected LSD test and standard error (SE).

Regression analysis was performed on the data from the salt and osmotic stress in different temperatures experiment. Germination values (\%) for both osmotic potential and $\mathrm{NaCl}$ concentration tests were fitted to a functional three-parameter logistic model:

$$
\mathrm{G}(\%)=\mathrm{G}_{\max } /\left[1+\left(\mathrm{x} / \mathrm{x}_{50}\right) \mathrm{G}_{\mathrm{rate}}\right]
$$

where $\mathrm{G}$ is the total germination (\%) at $\mathrm{NaCl}$ concentration $x$ and/or osmotic potential $\mathrm{x}, \mathrm{G}_{\max }$ is the maximum germination (\%), $x_{50}$ is the $\mathrm{NaCl}$ concentration and/or osmotic potential for $50 \%$ inhibition of the maximum germination, and $G_{\text {rate }}$ represents the slope.

SigmaPlot, for Windows software, Version 12.0 was used to fit functional three-parameter logistic models.

\section{Results}

\section{Alternating temperature and light regimes}

Initial germination of seeds of the E. caeruleum study populations differed among the different alternating temperature treatments (Fig. 1). Seed germination under alternating temperatures of population $\mathrm{P} 1$ was higher (with the only exception being P2 in $20 / 10^{\circ} \mathrm{C}$ ) than those of the other populations both in light/dark and complete darkness conditions. Maximum germination occurred with $25 / 15^{\circ} \mathrm{C}$ (day/night) for P1 (85.19\%). Seed germination in complete darkness was lower than in light/dark conditions for all populations. The initial seed germination of $\mathrm{P} 4$ was lower than the other populations in all alternating temperature treatments. Germination percentage was reduced in the highest alternating temperature treatment $\left(35 / 15^{\circ} \mathrm{C}\right)$ (Fig. 1).

\section{Constant temperature and light regime}

Germination of seeds of the E. caeruleum study populations occurred within the constant temperature range of $5^{\circ} \mathrm{C}$ to $30^{\circ} \mathrm{C}$ in the light/dark regime. Increase in temperature from 5 to $15^{\circ} \mathrm{C}$ increased seed germination for all populations in both light/dark and completes darkness photoperiods (Fig. 2). The greatest germination percentage for P1, P3 and P4 was observed at 10 and $15^{\circ} \mathrm{C}$, but seeds of $\mathrm{P} 2$ experienced maximum germination in the $15^{\circ} \mathrm{C}$ in light/dark regime (Fig. 2B). Germination decreased as temperature increased from 15 up to $30^{\circ} \mathrm{C}$ and germination reached zero at $35^{\circ} \mathrm{C}$, both in light/dark and darkness, for all populations (Fig. 2). Both P4 and P3 were exhibited a greater reduction in germination when subjected to temperatures higher than $15^{\circ} \mathrm{C}$ in both light regimes. For all populations, seed germination was lower in complete darkness than in the light/dark condition (Fig. 2).

\section{Osmotic potential and temperature}

For each population a functional three-parameter logistic model was fitted against the effect of osmotic potential on seed germination in different temperatures. The model predicted the seed germination parameter for populations in different osmotic potentials and temperatures (Fig. 3, Tab. 2). Seed germination of populations reduced as osmotic stress 

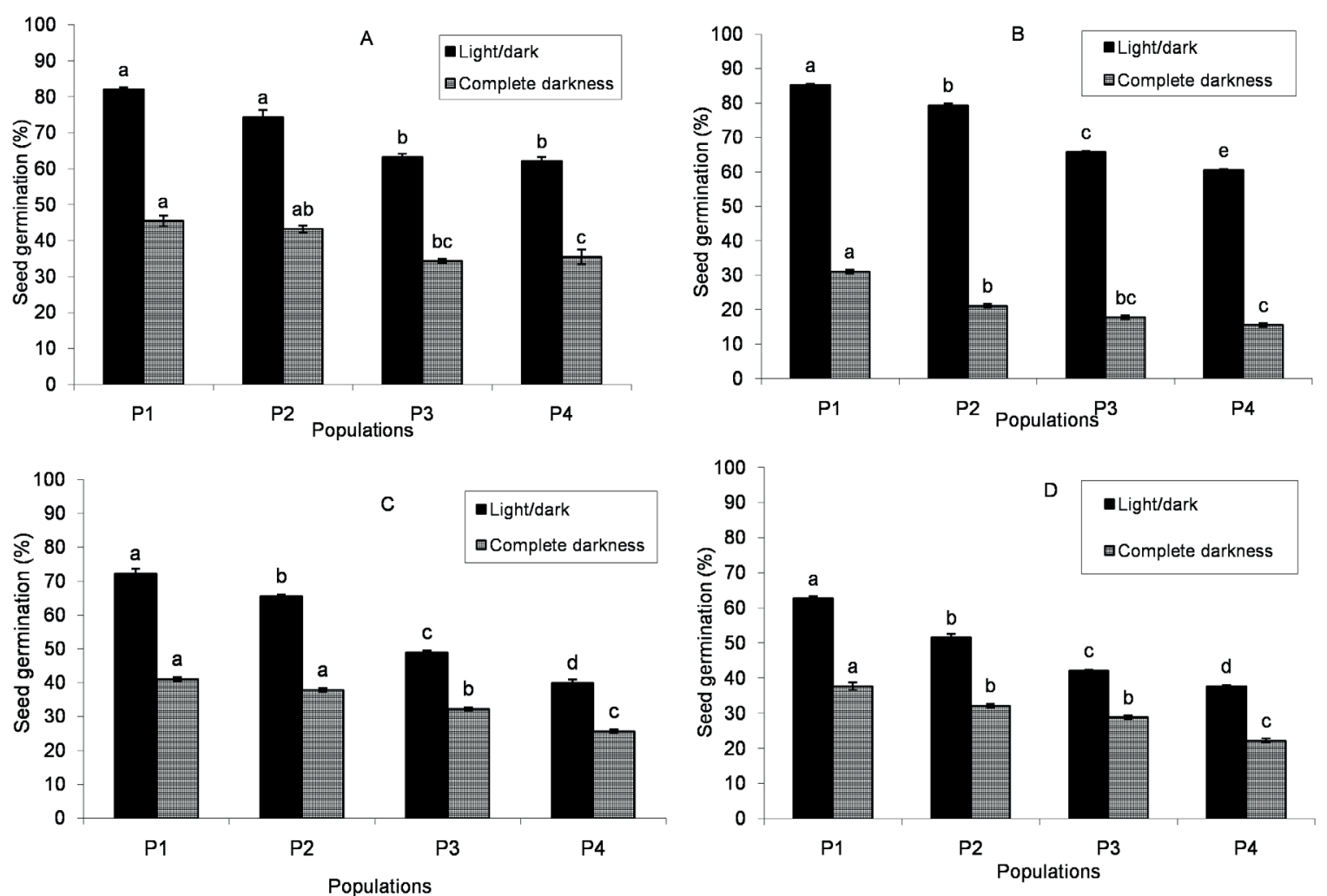

Figure 1. Effect of alternating temperatures consist of $A=20 / 10, B=25 / 15, C=30 / 10$ and $D=35 / 15^{\circ} C$ light/dark on seed germination of Eryngium caeruleum populations (P1, P2, P3 and P4) at 12/12 hours light/dark and complete darkness regimes. In each group, different letters at the tops of the standard error bars presents significant differences according to LSD test.
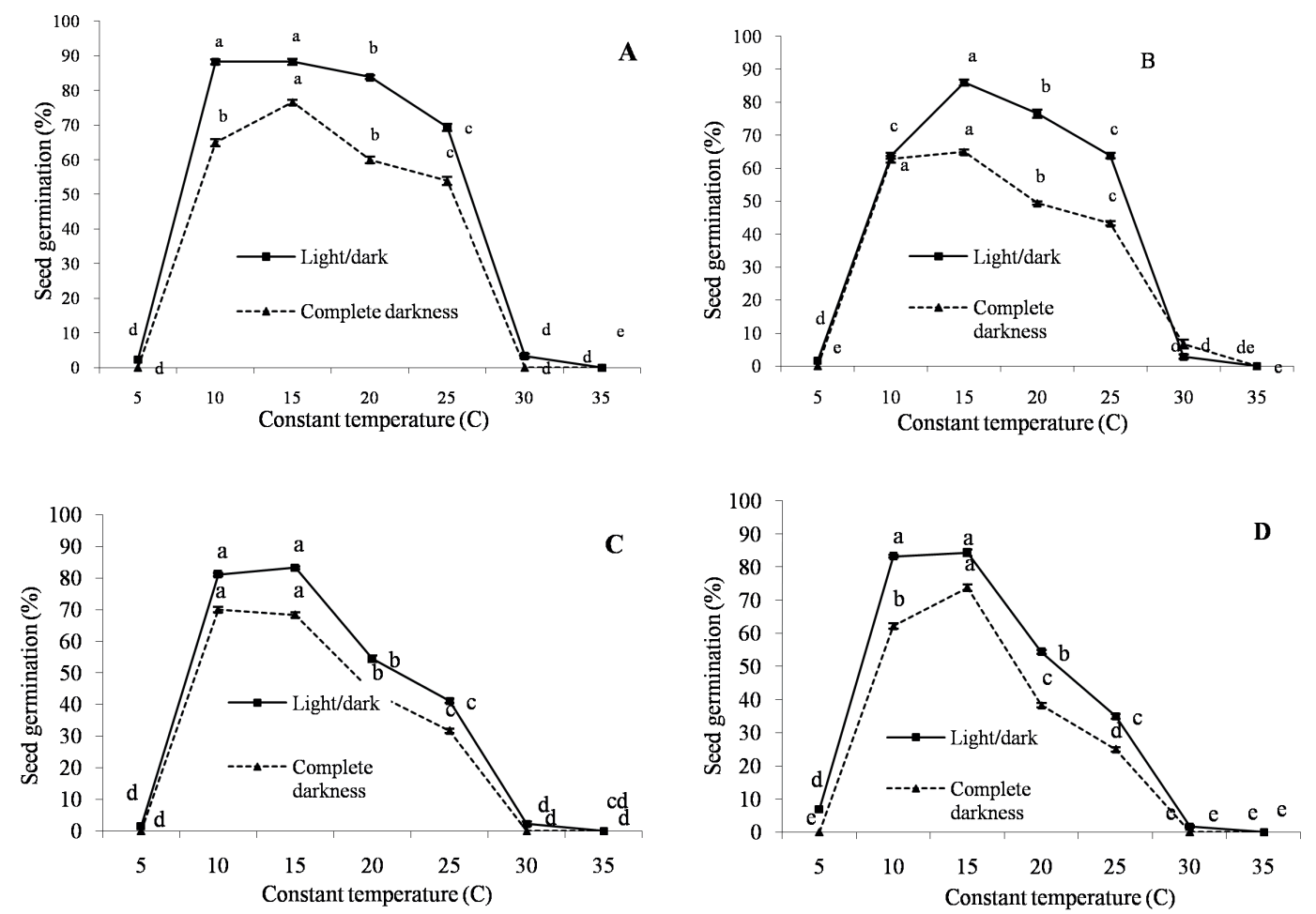

Figure 2. Effect of constant temperature on seed germination of Eryngium caeruleum populations at $12 / 12$ hours light/dark and complete darkness regimes. A, B, C and D are populations P1, P2, P3 and P4, respectively. In each light regime, different letters at the tops of the standard error bars presents significant differences according to LSD test. 
increased. The osmotic stress causing inhibition of $50 \%\left(\mathrm{X}_{50}\right)$ of seed germination increased as alternating temperatures increased (Tab. 2). With increasing temperature to $35 / 15^{\circ} \mathrm{C}$, the value of $\mathrm{X}_{50}$ increased (Tab. 2).

\section{$\mathrm{NaCl}$ concentration and temperature}

A three-parameter sigmoidal model was fitted to the seed germination data of P1, P2 and P3 (Fig. 4). Table 3 shows values of the estimated parameters for populations in the tested temperatures. However, the model could describe well seed germination for P4 under salt stress at different temperatures. Seed germination of P4 reached zero at the salt concentration of $40 \mathrm{mM}$ (Data not shown), which shows that $\mathrm{P} 4$ seed germination was more sensitive to salt stress. The maximum germination $\left(G_{\max }\right)$ of all populations decreased with increasing alternating temperatures. The salt stress causing $50 \%$ seed germination of $\mathrm{P} 1$ and $\mathrm{P} 2$ reduced as alternating temperatures increased (Tab. 3).

Germination in different alternating temperatures and saline stress treatments indicated that germination at lower temperatures was higher than those of higher temperatures. The populations varied in salt stress tolerance. Seed germination of $\mathrm{P} 2$ occurred under a wide range of $\mathrm{NaCl}$ concentration from $20 \mathrm{mM}$ up to $160 \mathrm{mM}$ except at temperature $35 / 15^{\circ} \mathrm{C}$ (day/night) (Fig. 4B). Germination of $\mathrm{P} 1$ was restricted to a narrower range of salinity, up to $80 \mathrm{mM}$, for those seeds incubated at temperature $35 / 15^{\circ} \mathrm{C}$, and also at $40 \mathrm{mM}$ under alternating temperatures $20 / 10^{\circ} \mathrm{C}$ and $25 / 15^{\circ} \mathrm{C}$ (day/night) (Fig. 4A). Seed germination of P3 was restricted to $40 \mathrm{mM}$ salinity at temperatures $25 / 15^{\circ} \mathrm{C}$ and $35 / 15^{\circ} \mathrm{C}$ (day/night) and germination was completely inhibited at higher salinities. At temperature $20 / 10{ }^{\circ} \mathrm{C}$ (day/night), $\mathrm{P} 3$ germinated in $\mathrm{NaCl}$ concentrations up to $80 \mathrm{mM}$, with germination reaching zero with an increase in salt stress to $160 \mathrm{mM}$ (Fig. 4C).

\section{pH solution}

Germination of seeds of the E. caeruleum study populations differed significantly among $\mathrm{pH}$ solutions. For all populations, seed germination occurred in a $\mathrm{pH}$ range of 5 to 8 . For all populations, the greatest germination observed was in $\mathrm{pH}$ 7. Among the populations, $\mathrm{P} 1$ had the highest germination rate (Fig 5).

Table 2. Parameters estimated for three-parametric logistic equation used in osmotic potential experiment in different temperature.

\begin{tabular}{|c|c|c|c|c|c|c|}
\hline Populations & Temperature $\left[{ }^{\circ} \mathrm{C}\right]$ & $G_{\max }$ & $x_{50}$ & $\mathbf{G}_{\text {rate }}$ & $\mathbf{R}^{2}$ & Three-parametric logistic equation \\
\hline & $20 / 10$ & 86.35 & 0.26 & 1.95 & 0.98 & {$\left[G(\%)=86.35 /\left[1+(x / 0.26)^{1.95}\right]\right.$} \\
\hline \multirow[t]{3}{*}{ P1 } & $25 / 15$ & 81.55 & 0.29 & 2.02 & 0.98 & {$\left[\mathrm{G}(\%)=81.55 /\left[1+(\mathrm{x} / 0.29)^{2.02}\right]\right.$} \\
\hline & $35 / 15$ & 56.47 & 0.62 & 27.98 & 0.99 & {$\left[G(\%)=56.47 /\left[1+(x / 0.62)^{27.98}\right]\right.$} \\
\hline & $20 / 10$ & 69.80 & 0.48 & 6.07 & 0.97 & {$\left[\mathrm{G}(\%)=69.80 /\left[1+(\mathrm{x} / 0.48)^{6.07}\right]\right.$} \\
\hline \multirow[t]{3}{*}{ P2 } & $25 / 15$ & 68.74 & 0.50 & 6.03 & 0.98 & {$\left[\mathrm{G}(\%)=68.74 /\left[1+(\mathrm{x} / 0.50)^{6.03}\right]\right.$} \\
\hline & $35 / 15$ & 52.06 & 0.52 & 5.00 & 0.99 & {$\left[G(\%)=52.06 /\left[1+(x / 0.52)^{5.00}\right]\right.$} \\
\hline & $20 / 10$ & 66.92 & 0.48 & 3.81 & 0.97 & {$\left[\mathrm{G}(\%)=66.92 /\left[1+(\mathrm{x} / 0.48)^{3.81}\right]\right.$} \\
\hline \multirow[t]{3}{*}{ P3 } & $25 / 15$ & 58.48 & 0.51 & 4.06 & 0.97 & {$\left[G(\%)=58.48 /\left[1+(x / 0.51)^{4.06}\right]\right.$} \\
\hline & $35 / 15$ & 39.15 & 0.62 & 15.79 & 0.97 & {$\left[G(\%)=39.15 /\left[1+(x / 0.62)^{15.79}\right]\right.$} \\
\hline & $20 / 10$ & 83.17 & 0.27 & 2.05 & 0.98 & {$\left[\mathrm{G}(\%)=83.17 /\left[1+(\mathrm{x} / 0.27)^{2.05}\right]\right.$} \\
\hline \multirow[t]{2}{*}{ P4 } & $25 / 15$ & 56.96 & 0.40 & 2.85 & 0.96 & {$\left[G(\%)=56.96 /\left[1+(x / 0.40)^{2.85}\right]\right.$} \\
\hline & $35 / 15$ & 39.72 & 0.44 & 3.18 & 0.98 & {$\left[\mathrm{G}(\%)=39.72 /\left[1+(\mathrm{x} / 0.44)^{3.18}\right]\right.$} \\
\hline
\end{tabular}

G: total germination (\%) in osmotic potential x; Gmax: maximum germination (\%); x50: osmotic potential for $50 \%$ maximum seed germination and Grate: curve slope.

Table 3. Parameters estimated for three-parametric logistic equation used in salt stress experiment in different temperatures.

\begin{tabular}{|c|c|c|c|c|c|c|}
\hline Populations & Temperature $\left[{ }^{\circ} \mathrm{C}\right]$ & $\mathbf{G}_{\max }$ & $x_{50}$ & $\mathbf{G}_{\text {rate }}$ & $\mathbf{R}^{2}$ & Three-parametric logistic equation \\
\hline & $20 / 10$ & 86.41 & 28.21 & 1.97 & 0.98 & {$\left[G(\%)=86.41 /\left[1+(x / 28.21)^{1.97}\right]\right.$} \\
\hline \multirow[t]{3}{*}{ P1 } & $25 / 15$ & 84.83 & 20.24 & 1.71 & 0.98 & {$\left[G(\%)=84.83 /\left[1+(x / 20.24)^{1.71}\right]\right.$} \\
\hline & $35 / 15$ & 62.59 & 17.98 & 1.31 & 1 & {$\left[G(\%)=62.59 /\left[1+(x / 17.98)^{1.31}\right]\right.$} \\
\hline & $20 / 10$ & 75.47 & 42.30 & 3.80 & 1 & {$\left[G(\%)=75.47 /\left[1+(x / 42.30)^{3.80}\right]\right.$} \\
\hline \multirow[t]{3}{*}{ P2 } & $25 / 15$ & 78.82 & 33.92 & 2.23 & 1 & {$\left[\mathrm{G}(\%)=78.82 /\left[1+(\mathrm{x} / 33.92)^{2.23}\right]\right.$} \\
\hline & $35 / 15$ & 51.25 & 28.88 & 2.24 & 1 & {$\left[\mathrm{G}(\%)=51.25 /\left[1+(\mathrm{x} / 28.88)^{2.24}\right]\right.$} \\
\hline & $20 / 10$ & 65.39 & 20.85 & 1.87 & 1 & {$\left[G(\%)=65.39 /\left[1+(x / 20.85)^{1.87}\right]\right.$} \\
\hline \multirow[t]{2}{*}{ P3 } & $25 / 15$ & 65.72 & 18.68 & 2.28 & 1 & {$\left[\mathrm{G}(\%)=65.72 /\left[1+(\mathrm{x} / 18.68)^{2.28}\right]\right.$} \\
\hline & $35 / 15$ & 42.14 & 24.99 & 3.26 & 1 & {$\left[G(\%)=42.14 /\left[1+(x / 24.99)^{3.26}\right]\right.$} \\
\hline
\end{tabular}

G: total germination (\%) in $\mathrm{NaCl}$ concentration $\mathrm{x} ; \mathrm{G}_{\max }:$ maximum germination (\%); $\mathrm{x}_{50}: \mathrm{NaCl}$ concentration for $50 \%$ maximum seed germination and $\mathrm{G}_{\text {rate: }}$ : curve slope. 

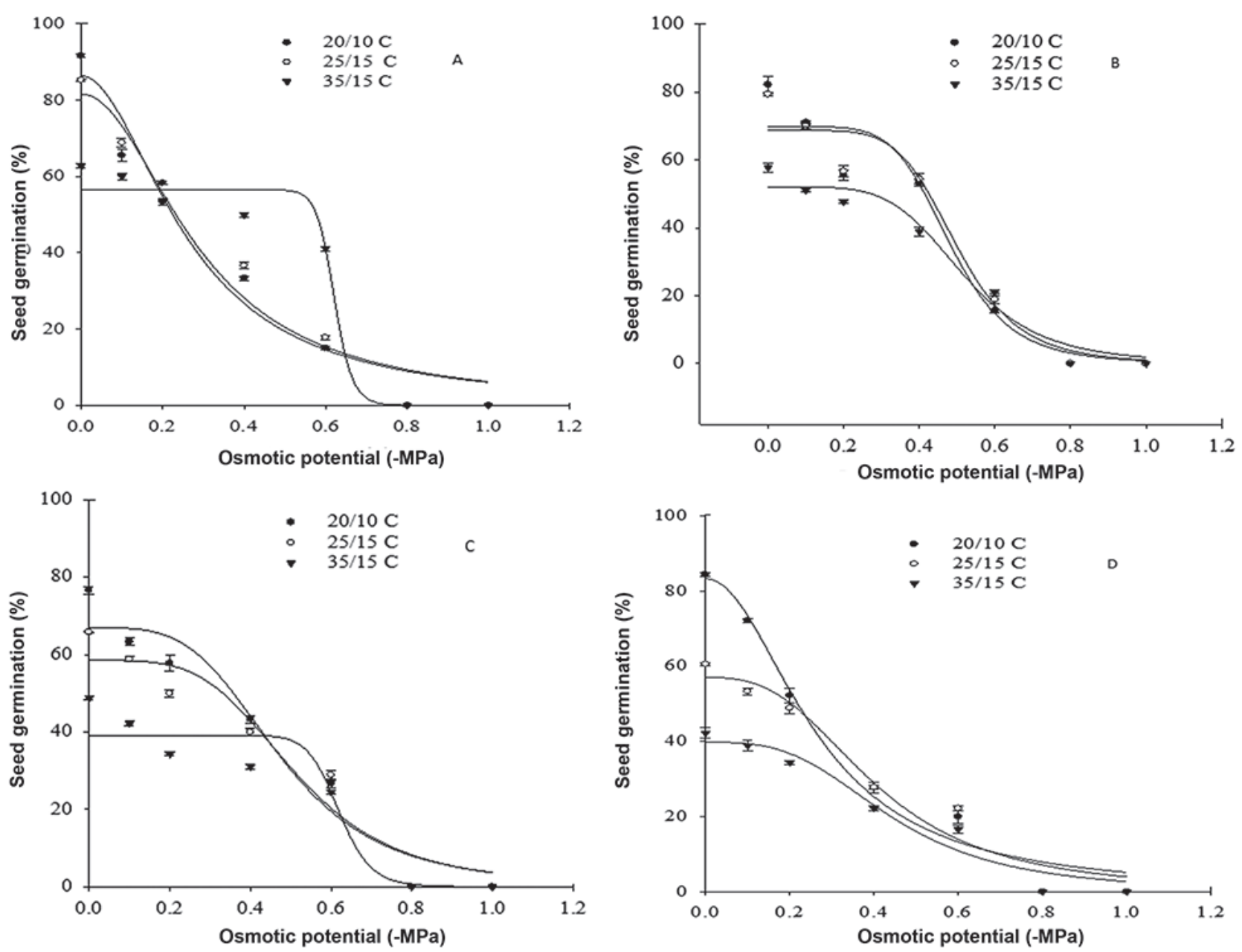

Figure 3. Effect of osmotic potential on seed germination of Eryngium caeruleum populations $(A=P 1 ; B=P 2 ; C=P 3 ; D=P 4)$ incubated in different temperatures in a 12 hour photoperiod for 15 days. The line represents the functional three-parameter logistic model $\{\mathrm{G}$ $(\%)=\mathrm{Gmax} /[1+(\mathrm{x} / \mathrm{x} 50)$ Grate $]\}$ fitted to the data. Vertical bars represents SE.

\section{Discussion}

In the present study, the optimum alternating temperature for $\mathrm{P} 1, \mathrm{P} 2$ and $\mathrm{P} 3$ was $25 / 15^{\circ} \mathrm{C}$ (day/night). Karimmojeny et al. (2014) showed a stimulatory effect of alternating temperature on seed germination of oriental mustard (Sisymbrium orientale). Temperature regulates seed germination by affecting enzymatic activity and several other metabolic processes (Chaturvedi et al. 2014). Alternating temperature plays an influential role in the balance of plant growth inhibitor and promoter hormones (Copeland \& McDonald 2001), where the inhibitor decreases during the low temperature cycle and the promoter increases during the high temperature cycle, leading to germination (Copeland \& McDonald 2001).

The optimal temperature for $\mathrm{P} 4$ was determined to be $20 / 10^{\circ} \mathrm{C}$ (day/night). Population $\mathrm{P} 4$ grows in a region at $1857 \mathrm{~m}$ elevation, and with a minimum and average temperature about $-15.40^{\circ} \mathrm{C}$ and $10.08^{\circ} \mathrm{C}$, respectively (Tab. 1). This population has greater fitness in lower temperatures, suggesting that the geographical and climatic factors of a region are influential factors in the response of seed germination to temperature.

For all populations, seed germination was lower under complete darkness (35-64 \%) than under an alternating photoperiod. The results show darkness is a limiting factor for seed germination of all populations, while photoperiod is an important factor for the enhancement of seed germination. Teuton et al. (2004) concluded that in some species seed germination occurs in the presence of light while others may germinate in light or dark regimes. Our findings are in agreement with Opeña et al. (2014), who showed that germination of E. glabrescens decreased by 52-92 \% when exposed to dark. These data suggest that seed germination of $E$. caeruleum will be reduced under plant canopy and litter shade and increasing planting depth.

Temperature is an important factor in determining the timing of germination (Fenner \& Thompson 2005). The optimum constant temperature for germination was found to be $10^{\circ} \mathrm{C}$ to $15^{\circ} \mathrm{C}$ for $\mathrm{P} 1, \mathrm{P} 3$ and $\mathrm{P} 4$, and $15^{\circ} \mathrm{C}$ for P3. Our data suggest lower $\left(5^{\circ} \mathrm{C}\right)$ and higher $\left(35^{\circ} \mathrm{C}\right)$ temperatures 

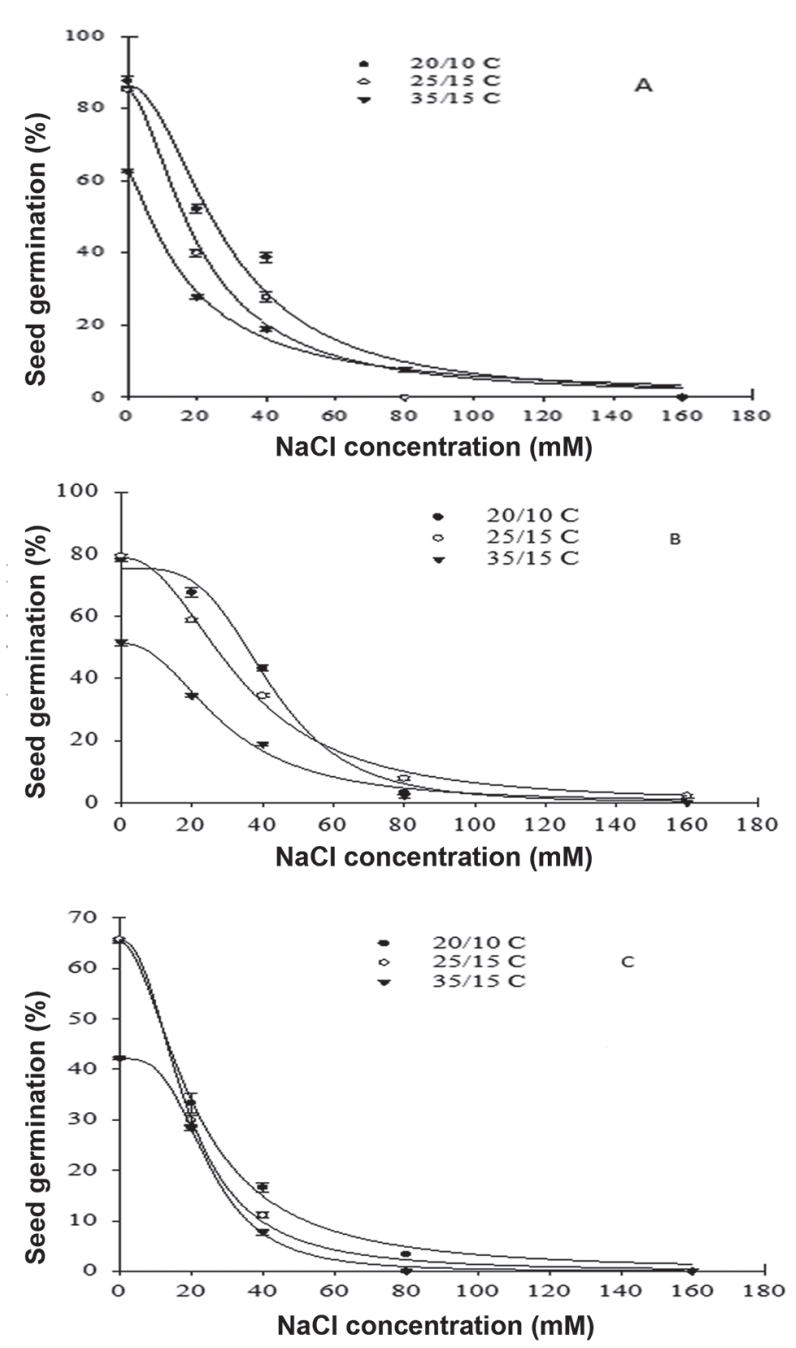

Figure 4. Effect of $\mathrm{NaCl}$ concentration on seed germination of Eryngium caeruleum populations $(\mathrm{A}=\mathrm{P} 1 ; \mathrm{B}=\mathrm{P} 2 ; \mathrm{C}=\mathrm{P} 3)$ incubated in different temperatures in a 12 hour photoperiod for 15 days. The line represents the functional three-parameter logistic model $\{G(\%)=G \max /[1+(x / x 50)$ Grate $]\}$ fitted to the data. Vertical bars represents $S E$.

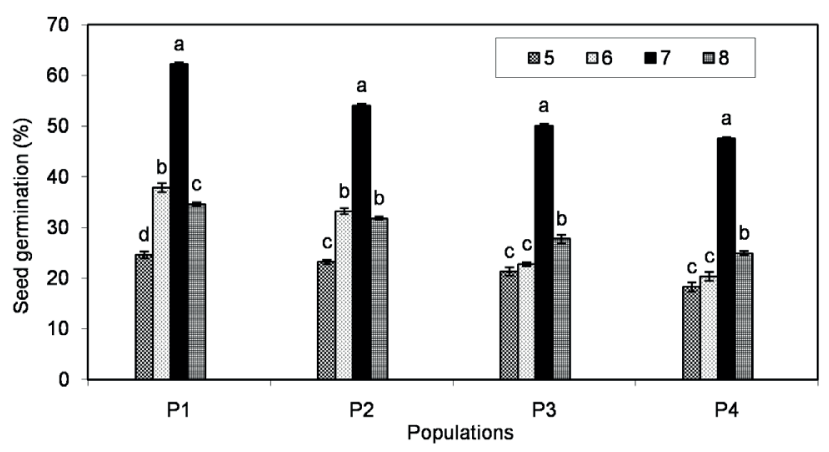

Figure 5. Effect of $\mathrm{pH}$ solutions on seed germination of Eryngium caeruleum population incubated in different temperatures in alternating temperature $25 / 15^{\circ} \mathrm{C}$ day/night and a 12 hour photoperiod for 15 days. In each population, different letters at the tops of the standard error bars present significant differences according to LSD test. inhibited germination of all populations. A possible reason for this is that low temperatures have inhibitory impacts on catabolic activity, while high temperatures denature proteins and inactivate certain enzymes (Maguire 1973). In the present study, the optimum temperature for germination varied among the different populations. Onen (2006) observed variation in optimum germination temperature among different seed lots of mugwort Artemisia annua.

Complete darkness reduced seed germination by up to $53 \%$, compared to the light/dark regime. Differences in seed germination imposed by light/dark and completedarkness regimes have been previously reported by Rezvani \& Zaefarian (2016) in hoary cress (Cardaria draba) and Rezvani et al. (2014) in shepherd's purse (Capsella bursapastoris).

Drought stress during seed germination can delay seedling emergence and reduce seedling survival. Furthermore, osmotic stress can simulate drought stress during germination. Germination of the study populations reduced with increasing osmotic stress at all temperatures. The negative impact of osmotic stress on germination was previously reported by Rezvani \& Zaefarian (2016) in hoary cress, and Rezvani et al. (2014) in shepherd's purse. Soil water potential is one of the factors that regulate seed water uptake. The rate of seed imbibition decreases with decreasing soil water potential causing a water deficit and, consequently, the decreased germination (Asgarpour et al. 2015).

Seed germination in both low levels of alternating temperature and osmotic stress was greater that higher levels. These data suggest that the distribution of $E$. caeruleum is limited to regions with low temperature and drought stress. Also, complete inhibition of germination at osmotic potentials $-0.8 \mathrm{MPa}$, indicate that E. caeruleum seeds are sensitive to high osmotic stress in soil, and that germination is restricted to temperate regions with moist soil. In northern Iran, germination of E. caeruleum begins in the middle of autumn, and a reduction in rain can potentially lead to a reduction and delay in seedling establishment.

Salt stress reduced seed germination. Seeds often germinate under no-saline conditions, and their germination decreases salinity increases (Khan \& Ungar 1998). Salinity stress influences seed germination by producing an external osmotic potential that prevents water uptake, and also causes toxic ion effects (Hosseini et al. 2003). Additionally, sodium ions can alter soil structure and fertility by replacing calcium and magnesium in the anion exchange process, thus leading to nutrient and water stress (Rao et al. 2008).

Without considering the temperature, seed germination was inhibited in a range of salinity from $40 \mathrm{mM}$ (for P4) to $160 \mathrm{mM}$ (for P2). Therefore, E. caeruleum germination was found to be sensitive to moderately sensitive to saline.

Germination of seeds of the E. caeruleum study populations was restricted to a $\mathrm{pH}$ range of 5 to 7 , with germination in $\mathrm{pH} 5,6$ and 8 exhibiting a reduction in germination of about $45 \%-60 \%$ compared to $\mathrm{pH} 7$. Our 
data suggests that soil $\mathrm{pH}$ may acts as a limiting factor for the distribution of E. caeruleum.

Plants vary in their response to $\mathrm{pH}$. Some species require limited range of $\mathrm{pH}$ to germinate. Pérez-Fernández et al. (2006) showed that $\mathrm{pH}$ lower or higher than seven reduced seed germination of Medicago arabica, Epilobium hirsutum, Foeniculum vulgare, Daucus carota, Thapsia villosa, Cynosurus cristatus, Dactylis glomerata and Rumex crispus. Goubitz et al. (2003) concluded that high $\mathrm{pH}$ negatively affects seed germination of Pinus halepensis. On the other hand, some research has revealed that soil $\mathrm{pH}$ is not a limiting factor for many species of plants, such as spotted spurge (Chamaesyce maculata) (Asgarpour et al. 2015), buffalobur (Solanum rostratum) (Wei et al. 2009), cadillo (Urenalobata) (Wang et al. 2009), sheep sorrel (Rumex acetosella) (Yazdi et al. 2013) and hoary cress (Rezvani \& Zaefarian 2016). Consequently, germination over a wide $\mathrm{pH}$ range indicates that $\mathrm{pH}$ would not be a limiting factor for colonizing different habitats for these species.

\section{Conclusions}

In summary, the optimum alternating temperature for germination of E. caeruleum was $25 / 15^{\circ} \mathrm{C}$ in a light/ dark regime, and the optimum constant temperature was $10-15^{\circ} \mathrm{C}$, also in a light/dark regime. These data show that successful germination of E. caeruleum may be limited to temperate climates. Seed germination of E. caeruleum is sensitive to drought stress, while soil with adequate moisture favors germination. Germination percentage decreased and to the point of inhibition at moderate concentrations of $\mathrm{NaCl}$, indicating that salt stress could be a serious obstacle to germination and establishment of E. caeruleum. Extreme levels of high and low soil $\mathrm{pH}$ also restricted seed germination, and thus soil $\mathrm{pH}$ might also be an important limiting factor to this species colonizing new areas. Given the previous lack of data about the conditions for E. caeruleum seed germination, the information generated in this study is crucial to understanding the environmental conditions necessary for seed germination and seedling establishment in different habitats. These data will help to predict the potential distribution of E. caeruleum in new habitats in the future.

\section{Acknowledgements}

The authors are grateful for the financial support provided by the Office of the Vice-Chancellor for Research at the Qaemshahr Branch of Islamic Azad University, in Qaemshahr, Iran.

\section{References}

Amini V, Zaefarian F, Rezvani M. 2015. Interspecific variations in seed germination and seedling emergence of three Setaria species. Brazilian Journal of Botany 38: 539-545.
Armitage AM. 1993. Specialty cut flowers. Portland, Varsity Press, Timber Press.

Asgarpour R, Ghorbani R, Khajeh-Hosseini M, Mohammadvand E, Chauhan BS. 2015. Germination of spotted spurge (Chamaesyce maculata) seeds in response to different environmental factors. Weed Science 63: 502-510.

Bazzaz FA. 1979. The physiological ecology of plant succession. Annual Review of Ecological System 10: 351-371.

Chachalis D, Reddy KN. 2000. Factors affecting Campsis radicans seed germination and seedling emergence. Weed Science 48: 212-216.

Chaturvedi P, Bisht D, Tiwari Pandey S. 2014. Effects of temperature, moisture and salinity on seed germination of Artemisia annua L. grown under Tarai conditions of Uttarakhand. Journal of Applied Horticulture 16: 231-234.

Copeland LO, McDonald MB. 2001. Principles of seed science and technology. 4th. edn. Norwell, Kluwer Academic Publisher.

Daneshfar E, Noghondar MA, Zarifian M, Azizi M. 2014. Study on dormancy breaking Eryngium caeruleum M. B. (Apiaceae) seeds by different levels of $\mathrm{KNO}_{3}$ and salicylic acid. Mashahd, 3rd National Congress on Medicinal Plants.

Everett TH. 1960. New illustrated encyclopedia of gardening unabridged. Vol. 2. New York, Greystone Press.

Fenner M, Thompson K. 2005. The ecology of seeds. 2nd. edn. New York, Cambridge University Press.

Finch-Savage WE, Leubner-Metzger G. 2006. Seed dormancy and the control of germination. New Phytologist 171: 501-523.

Ghahreman A. 1997. Flora of Iran. Tehran, Research Institute of Forests and Range Lands.

Goubitz S, Werger MJA, Néeman G. 2003. Germination response to fire related factors of seeds from non-serotinous and serotinous cones. Plant Ecology 169: 195-204.

Hosseini MK, Powell AA, Bingham IJ. 2003. The interaction between salinity stress and seed vigor during germination of soybean seeds. Seed Science and Technology 31: 715-725.

Karimi H. 2001. Weeds of Iran. Tehran, Center for Academic Publications. Karimmojeny H, Rezvani M, Zaefarian F, Nikneshan P. 2014. Environmental and maternal factors affecting on oriental mustard (Sisymbrium orientale L.) and musk weed (Myagrum perfoliatum L.) seed germination. Brazilian Journal of Botany 37: 121-127.

Khan MA, Ungar IA. 1998. Germination of salt tolerant shrub Suaeda fruticosa from Pakistan: Salinity and temperature responses. Seed Science and Technology 26: 657-667.

Khoshbakht K, Hammer K, Pistrick K. 2006. Eryngium caucasicum Trautv. cultivated as a vegetable in the Elburz Mountains (Northern Iran). Journal of Genetic Research and Crop Evolution 54: 445-448.

Krawczyk A, Krawczyk J. 2000. Ecotopical differentiation of Homogyne alpina (L.) Cass.in the Karkonosze Montains. Opera Corconitica 37: 244.

Linhart YB, Grant MC. 1996. Evolutionary significance of local genetic differentiation in plants. Annual Review Ecological Systems 27: 237277.

Maguire JD. 1973. Physiological disorders in germinating seeds induced by the environment. In: Heydecker W. (ed.) Seed Ecology. London, Butterworths. p. 289-310.

Michael BE, Kaufaman MR. 1973. The osmotic potential of polyethylene glycol 6000. Plant Physiology 51: 914-916.

Onen H. 2006. The influence of temperature and light on seed germination of mugwort (Artemisia vulgaris L.). Journal of Plant Disease and Protection 20: 393-399.

Opeňa JL, Chauhan BS, Baltazar AM. 2014. Seed germination ecology of Echinochloa glabrescens and its implication for management in rice (Oryza sativa L.). PLoS ONE 9: e92261. Doi:10.1371/journal. pone.0092261.

Pérez-Frnández MA, Calvo-Magro E, Montanero-Fernández J, OyolaVelasco JA. 2006. Seed germination in response to chemicals: Effect of nitrogen and $\mathrm{pH}$ in the media. Journal of Environment and Biology 27: 13-20.

Peters J. 2000. Association of official seed analysis tetrazolium testing handbook. Contribution No. 29. 1st. edn. Lincoln, Association of Official Seed Analysis. 


\section{Mohammad Rezvani and Faezeh Zaefarian}

Pimenov MG, Leonov MV. 1993. The genera of the Umbelliferae. Kew, Royal Botanic Gardens.

Rao N, Dong L, Li J, Zhang H. 2008. Influence of environmental factors on seed germination and emergence of American sloughgrass (Beckmannia syzigachne). Weed Science 55: 264-272.

Rezvani M, Yazdi SA. 2013. Factors affecting seed germination of black nightshade (Solanum nigrum). Acta Botanica Hungarica 55: 397-408,

Rezvani M, Zaefarian F. 2016. Hoary cress (Cardaria draba (L.) Desv.) seed germination ecology, longevity and seedling emergence. Plant Species Biology 31: 280-287.

Rezvani M, Zaefarian F, Amini V. 2014. Effect of chemical treatments and environmental factors on seed dormancy and germination of
Shepherd's purse (Capsella bursapastoris (L.) Medic.). Acta Botanica Brasilica 28: 495-501.

Teuton TC, Brecke BJ, Unruh JB, MacDonald GE, Miller GL, Ducar JT. 2004. Factors affecting seed germination of tropical signal grass (Urochloa subquadripara). Weed Science 52: 376-381.

Wang J, Ferrell J, MacDonald G, Sellers B. 2009. Factors affecting seed germination of cadillo (Urena lobata). Weed Science 57: 31-35.

Wei S, Zhang C, Li X, et al. 2009. Factors affecting buffalobur (Solanum rostratum) seed germination and seedling emergence. Weed Science 57: 521-525.

Yazdi SAF, Rezvani M, Mohassel MHR, Ghanizadeh H. 2013. Factors affecting seed germination and seedling emergence of sheep sorrel (Rumex acetosella). Romanian Agricultural Research 30: 373-380. 